\title{
Regulation of Protease Nexin-1 Expression in Cultured Schwann Cells Is Mediated by Angiotensin II Receptors
}

\author{
Alicia Bleuel,' Marc de Gasparo, ${ }^{2}$ Steven Whitebread, ${ }^{3}$ Irene Püttner, ${ }^{3}$ and Denis Monard' \\ ${ }^{1}$ Friedrich Miescher Institut, ${ }^{2}$ Pharmaceutical Division of Ciba, and ${ }^{3}$ Biotechnology Department of Ciba, Basel, Switzerland
}

Protease nexin-1 (PN-1) is a potent inhibitor of serine proteases, such as thrombin and plasminogen activators, which is secreted into the extracellular space. Since PN-1 is induced following lesion of the sciatic nerve, the effect of substances known to accumulate at the site of injury was examined in primary cultures of Schwann cells. Among the cytokines, growth factors, mitogens, neurotrophins, and neuroactive peptides analyzed, only angiotensin II (Ang II), calcitonin gene-related peptide (CGRP), and vasoactive intestinal peptide (VIP) were found to regulate the expression of PN-1 on Schwann cells. While Ang II and CGRP caused downregulation, VIP acted as a positive modulator of PN-1. Displacement of Ang II binding using the selective ligands losartan and CGP 42112 led to a severalfold increase of PN-1 protein and mRNA over basal levels, indicating that the observed effect was mediated by specific binding sites. Indeed, the presence of $\mathrm{AT}_{1}$ and $\mathrm{AT}_{2}$ angiotensin receptor subtypes was demonstrated in cultured Schwann cells as well as in the rat sciatic nerve. Moreover, the detection of angiotensinogen- and renin-mRNA in these cultures suggested an endogenous production of Ang II. This data identified one of the mechanisms regulating PN-1 synthesis. Altogether our results indicate that neuropeptides can differentially control the proteolytic activity of the microenvironment, providing new aspects of neuron-glia interactions in the intact tissue and following nerve injury.

IKey words: regulation of protease nexin-1 synthesis, serine protease inhibitor(s), primary Schwann cells, renin-angiotensin system, angiotensin II receptors, neuroactive peptides, neuron-glia interactions]

Cultured glial cells release a potent serine protease inhibitor with neurite-promoting activity (Monard et al., 1973; Guenther et al., 1985; Stone et al., 1987). Following the determination of the amino acid sequence, this $43 \mathrm{kDa}$ protein was named gliaderived nexin (GDN) (Gloor et al., 1986). It was subsequently shown that GDN and protease nexin-1 (PN-1), a thrombin inhibitor released by cultured human skin fibroblasts, are identical

\footnotetext{
Feb. 25, 1994; revised July 1, 1994; accepted July 13, 1994.

We thank Franz Fischer for oligonucleotide synthesis; Dr. Florence Botteri, Simone Niclou, and Dr. Henrik Frne for technical advice; and Drs. Andrew Matus, Pico Caroni, Kevin Ashbridge, and Florence Botteri for critical reading of this manuscript.

Correspondence should be addressed to Dr. Denis Monard, Friedrich Miescher Institut, P.O. Box 2543, 4002 Basel, Switzerland.

Copyright (C) 1995 Society for Neuroscience $0270-6474 / 95 / 150750-12 \$ 05.00 / 0$
}

(McGrogan et al., 1988). As recent results demonstrate the presence of the inhibitor in a variety of cells, including neurons (Mansuy et al., 1993; Reinhard et al., 1994), the more general term protease nexin- 1 is now used. The balance between proteases and protease inhibitors determines the proteolytic activity of the extracellular microenvironment, which may play an important role in cellular events such as migration, differentiation, and plasticity of neuronal cells (reviewed by Monard, 1988; Festoff et al., 1990; Pittman, 1990).

Ischemia-induced lesions in the hippocampus and injection of 6-hydroxydopamine or excitotoxic agents (ibotenic acid, $N$-methyl-D-aspartate, and quisqualate) in the substantia nigra cause upregulation of $\mathrm{PN}-1$ synthesis in astrocytes (Hoffmann et al., 1992; Scotti et al., 1994). In the olfactory system, where constant degeneration and regeneration take place throughout life, PN-1 is constitutively expressed at high levels (Reinhard et al., 1988). In the peripheral nervous system, injury of the rat sciatic nerve also triggers induction of $\mathrm{PN}-1$ synthesis in a subpopulation of Schwann cells localized at the distal site of the injury (Meier et al., 1989). As in vitro thrombin can cause the collapse of neurites (Gurwitz and Cunningham, 1988; Suidan et al., 1992), and as PN-1 is the most potent endogenous thrombin inhibitor known today, the presence of PN-1 at sites of lesion suggests that it could protect remaining structures from prolonged and extensive proteolytic attacks. Alternatively, it remains to be seen if the neurite-promoting activity associated with PN-1 contributes in vivo to the permissive conditions supporting the regeneration of peripheral nerves or even to the abortive sprouting observed after lesion in the CNS. In any case, more knowledge about the molecular mechanisms regulating PN-1 synthesis is imperative.

In order to gain insight into the class of molecules involved in PN-1 regulation in glial cells, diverse injury-associated factors (reviewed by Fawcett and Keynes, 1990) were tested on Schwann cell cultures. Only treatment with the peptides angiotensin II (Ang II), calcitonin gene-related peptide (CGRP), and vasoactive intestinal peptide (VIP) affected PN-1 levels. In fact, these peptides have been shown to have a broad spectrum of physiological effects. In the nervous system, they may act as mitogens, neurotrophic factors, and/or neurotransmitters (for reviews see Laufer and Changeux, 1987; Gozes et al., 1989; Bunneman et al., 1991; Dumoulin et al., 1992; Gressens et al., 1993). Here we report that Ang II downregulates PN-1 expression in cultured Schwann cells, and that treatment with selective blockers of the angiotensin receptors causes a five- to eightfold increase in PN-1 expression over the basal level. Our results also provide support for an autocrine renin-angiotensin system in dissociated cell cultures derived from the sciatic nerve. 


\section{Materials and Methods}

Materials. Sprague-Dawley rats were obtained from the Ciba animal care facilities. Recombinant human IL-1 $\alpha$ and IL-1 $\beta$, human Ang II (hypertensin), losartan (DuP 753), CGP 42112, PD 123319, substance $\mathrm{P}$, and ANP were synthesized and obtained from Ciba, Basel. Recombinant human renin was kindly provided by Dr. M. Gruetter (Biotechnology Department of Ciba, Basel), TGF $\beta$ by Dr. M. Sporn (National Cancer Institute, Bethesda), recombinant human acidic FGF by Dr. Y. Courtois (INSERM, Paris), basic-FGF by Dr. M. Sensenbrenner (Institut de Neurochimie CNRS, Strasbourg), GGF by Dr. P. Stroobant and Dr. J. Brockes (Ludwig Institute for Cancer Research, London), CNS-myelin membrane fraction by Dr. P. Caroni (Friedrich Miescher Institut, Basel), NGF by Dr. H. Thoenen (Max-Planck Institut für Psychiatrie, München), recombinant NT-3 and BDNF by Dr. Y. Barde (Max-Planck Institut für Psychiatrie, München), CNTF by Dr. M. Sendtner (Max-Planck Institut für Psychiatrie, München), the PAI-1 cDNA probe by Dr. A. Sappino (University of Geneva Medical School), and the rat angiotensinogen- and renin-cDNA probes by Dr. M. Paul (Ruprecht-Karls-Universität, Heidelberg). EGF was purchased from Biomedical Technology Inc. (Stoughton, USA), recombinant human PDGF from BRL (Gaithersburg, MD), enalapril from Merck (Darmstadt, Germany), vasopressin from Calbiochem (La Jolla, CA), CCK and CGRP from Bachem (Bubendorf, Switzerland), somatostatin from Sigma (St. Louis, MO), oxytocin from Boehringer (Mannheim, Germany), and VIP from Peninsula Labs (Belmont, USA).

Cultures of Schwann cells. Primary Schwann cells were prepared essentially as described by Brockes et al. (1979). Briefly, sciatic nerves from 3- to 4-d-old rats were enzymatically dissociated by incubation in Hank's salt solution $\left(\mathrm{Ca}^{2+}, \mathrm{Mg}^{2+}\right.$ free) containing $0.03 \%$ collagenase and $0.25 \%$ trypsin $\left(60 \mathrm{~min}, 37^{\circ} \mathrm{C}\right)$. After digestion, the supernatant was removed and the nerves were triturated in Dulbecco's modified Eagle's medium (DMEM) and 10\% fetal calf serum (FCS). The resulting singlecell suspension (1-1.4 $\times 10^{5}$ cells/nerve) was collected by centrifugation $(500 \times g, 10 \mathrm{~min})$ and resuspended in pyruvate-free DMEM supplemented with $10 \%$ FCS (Sebak), penicillin G $(100 \mathrm{U} / \mathrm{ml})$, and streptomycin $(100 \mu \mathrm{g} / \mathrm{ml})$. Cells were plated on tissue culture dishes (Corning) coated with collagen $\left(40 \mu \mathrm{g} / \mathrm{ml}\right.$ PBS, Serva) at a density of $4 \times 10^{6}$ cells per $60 \mathrm{~mm}$ dish. Cultures were kept in a $5 \% \mathrm{CO}_{2} / 95 \%$ humidified air incubator at $37^{\circ} \mathrm{C}$. To eliminate proliferating fibroblasts, cells were exposed to two treatments with the antimitotic agent cytosine arabinoside $\left(10^{-5} \mathrm{M}\right)$ : on day 1 (after plating) for $48 \mathrm{hr}$, and on day 4 for $24 \mathrm{hr}$. Except for the serum contained in the medium, no additional mitogen was added to the cells. All experiments were performed 8-10 d after plating and with cultures containing at most $5 \%$ fibroblasts. Fibroblasts can clearly be distinguished from Schwann cells by the size and morphology of the nucleus visualized by Hoechst staining.

Cultures of fibroblasts. Fibroblasts were enriched by preplating the above prepared cell suspension for $30 \mathrm{~min}$ on polyornithine-coated dishes $(0.5 \mathrm{mg} / \mathrm{ml} \mathrm{PBS})$. This method is based on the differential adhesion properties of fibroblasts and Schwann cells. The faster-adhering fibroblasts enriched in this way were passed 2-3 times during the next 8-10 d. The resulting cultures contained only $1-3 \%$ Schwann cells.

Peritoneal macrophages. Macrophages were prepared and activated as described previously (Baichwal et al., 1988). They were cultured in DMEM $/ 10 \%$ FCS at a density of $1-2 \times 10^{6}$ cells $/ \mathrm{cm}^{2}$ and activated with lipopolysaccharide (LPS) $(70 \mu \mathrm{g} / \mathrm{ml})$, phorbol myristate acetate (PMA) $(5 \mathrm{ng} / \mathrm{ml})$, and ionomycin (100 $\mathrm{nM})$, or CNS-myelin membrane fraction for 24 and $48 \mathrm{hr}$. The resulting conditioned media were used diluted $1: 1$ in fresh DMEM/10\% FCS. Mcdia containing the various activating drugs or conditioned by nonactivated macrophages were used as controls.

Immunocytochemistry. PN-1 protein was detected in cultured cells using the monoclonal antibody 4B3. An alternative protocol was established for this purpose: cultures were fixed for $20 \mathrm{~min}$ with PBS containing $15 \%$ saturated picric acid and $4 \%$ paraformaldehyde. After being washed three times with PBS, fixed cells were permeabilized for 5 min with $0.2 \%$ Triton X-100 in PBS and then treated for 1 min with $0.4 \% \mathrm{SDS}$ in $1.5 \mathrm{M}$ Tris/ $\mathrm{HCl}$ (pH 8.8). Following blocking ( $20 \mathrm{~min}$ in $0.2 \%$ Triton $\mathrm{X}-100 / 10 \% \mathrm{FCS}$ ), incubation with the primary antibody (1:500 dilution of ascites preparation in blocking solution) took place overnight at $4^{\circ} \mathrm{C}$. After three washes with Triton-PBS, cells were incubated for $1 \mathrm{hr}$ with FITC-conjugated secondary antibody (Jackson Immuno Research) diluted 1:100 in blocking solution. The petri dish was finally washed three times with Triton-PBS and mounted in glyc-
erin-PBS. All steps were carried out at room temperature unless otherwise indicated.

SDS-PAGE and immunoblotting. These steps were performed essentially as described by Reinhard et al. (1988). Instead of rabbit polyclonal antibodies to PN-1, we used the monoclonal 4B3 (1:1000 dilution of ascites preparation).

Drug treatment. Prior to drug addition and in order to remove traces of serum proteins, cells were washed twice with DMEM. The various agents were added to the cultures in serum-free DMEM supplemented with $5 \mu \mathrm{g} / \mathrm{ml}$ insulin, $5 \mu \mathrm{g} / \mathrm{ml}$ transferrin, $5 \mathrm{ng} / \mathrm{ml}$ sodium selenite, 16 $\mu \mathrm{g} / \mathrm{ml}$ putrescine, $10 \mathrm{ng} / \mathrm{ml}$ progesterone, and $0.2 \mathrm{mg} / \mathrm{ml}$ stripped BSA as carrier. All treatments were based on single-drug administration, even for incubations longer than $24 \mathrm{hr}$.

Quantitation of secreted $P N-I$. A two-site enzyme-linked immunosorbent assay (ELISA) with a detection limit of $0.1 \mathrm{ng}$ PN-1 per $100 \mu 1$ conditioned medium was performed according to the method described by Meier et al. (1989).

Northern blot analysis. Total RNA was extracted in a guanidium thiocyanate solution according to Chomczynski and Sacchi (1987). The epineurium of sciatic nerves from P14 and adult animals have been removed prior to RNA isolation. RNA samples were fractionated by electrophoresis on a $0.8 \%$ agarose-formaldehyde gel and capillary transferred to a nylon membrane (Boehringer) overnight in $10 \times$ SSC. Staining of ribosomal RNA with $0.04 \%$ methylene blue solution confirmed the presence of equal amounts of RNA on all lanes. Hybridization of the membranes was performed as previously described by Mansuy et al. (1993), using $10^{6} \mathrm{cpm} / \mathrm{ml}$ of the various ${ }^{3} \mathrm{P}$-labeled probes. The rat PN-1 cDNA probe corresponds to a $1.3 \mathrm{~kb}$ XhoI-XbaI DNA fragment, the rat $A T$, probe to a PCR-generated $1.3 \mathrm{~kb}$ SmaI-SmaI fragment, and the rat PAI-I probe to a 726 bp PstI-ApaI fragment.

$R T-P C R$ amplification and Southern blot analysis. Total RNA $(2 \mu \mathrm{g})$ was reverse transcribed using a $(\mathrm{dT})_{17}$ primer as described by Kawasaki (1990). The primers used for the amplification of the rat AOGEN transcript were 5'-ACGCCCAGAACAACTTCTCCG-3' (nucleotides 10051025, sense) and 5'-CTACACAGGAGGCATCACACC-3' (nucleotides 1489-1509, antisense), and for renin, 5'-GCTCCCTGCAGTTGATCATGC-3' (nucleotides 935-945, sense) and 5'-GTCACTGGGTGACAGAGGAGC-3' (nucleotides 1242-1262, antisense). The PCR was carried out as follows: five cycles of $1 \mathrm{~min}$ at $94^{\circ} \mathrm{C}, 1 \mathrm{~min}$ at $55^{\circ} \mathrm{C}, 2$ min at $72^{\circ} \mathrm{C}$, and 30 cycles of $1 \mathrm{~min}$ at $94^{\circ} \mathrm{C}, 1 \mathrm{~min}$ at $60^{\circ} \mathrm{C}, 2 \mathrm{~min}$ at $72^{\circ} \mathrm{C}$. The Taq DNA polymerase as well as the MMV-reverse transcriptase were purchased from Boehringer.

Samples of the reaction mix $(15 \mu \mathrm{l})$ were electrophoresed on $2 \%$ agarose gels, stained with ethidium bromide, and further treated for Southern blot analysis according to standard procedures (Maniatis et al., 1987), using $10^{6} \mathrm{cpm} / \mathrm{ml}$ of the various ${ }^{32} \mathrm{P}$-labeled probes. The rat AOGENcDNA probe corresponds to a $1.3 \mathrm{~kb}$ StuI/NCOI fragment and the rat renin probe to a $1.3 \mathrm{~kb}$ HindIII/BamHI fragment.

Membrane preparation and Ang II binding assays. These were performed as described by Whitebread et al. (1989). Briefly, cells were washed with PBS and harvested using a rubber policeman. After homogenization in $20 \mathrm{~mm}$ sodium bicarbonate with a Polytron and centrifugation at $60,000 \times \mathrm{g}$ for $30 \mathrm{~min}$, the pellet was resuspended in 50

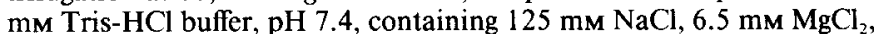
$1 \mathrm{~mm}$ EDTA, and $2 \mathrm{mg} / \mathrm{ml}$ BSA. Finally, a cocktail of peptidase inhibitors (phosphoramidon, leupeptin, antipain, and bestatin, each at 1.25 $\mu \mathrm{g} / \mathrm{ml}$ ) was added. The membrane preparation was kept in aliquots at $-80^{\circ} \mathrm{C}$ until used.

Binding assays consisted of competition experiments, which were performed using ${ }^{125}$ I-Ang II and increasing amounts of unlabeled Ang II, losartan, or CGP 42112. In a total reaction volume of $250 \mu \mathrm{l}$, 20$60 \mathrm{mg}$ membrane protein was incubated with $175 \mathrm{pm}$ labeled Ang II \pm unlabeled competitors for $1 \mathrm{hr}$ at $25^{\circ} \mathrm{C}$. The reaction was terminated by adding ice-cold PBS. Free and bound ${ }^{125}$ I-Ang II were separated by filtration through Whatman GF/F filters, which were washed twice with $4 \mathrm{ml}$ ice-cold PBS. The bound fraction, trapped on the filter paper, was counted in a $\gamma$-counter (Pharmacia). Binding constants were calculated from the competition curves using the program LIGAND.

\section{Results}

Immunocytochemistry and immunoblot analysis of cultures derived from dissociated sciatic nerves confirmed previous data (Meier et al., 1989), suggesting that Schwann cells are the main source of PN-1 in the peripheral nervous system. Staining per- 


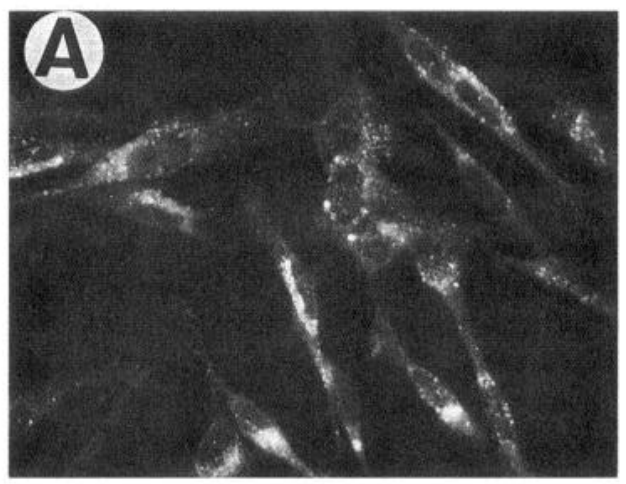

Figure 1. Schwann cells are the main source of PN-1 in cultures derived from dissociated sciatic nerves. Immunocytochemistry and immunoblotting were performed with the anti-PN-1 monoclonal antibody 4B3, diluted 1:500 and $1: 1000$, respectively. $A-C$, Immunofluorescence staining of primary Schwann cell cultures, previously fixed in picric acid/paraformaldehyde solution and permeabilized. $B$, Negative control, analogous to $A$ but omitting the first antibody. $D$, Hoechst staining of the field shown in $C$; the small nucleus identifies a Schwann cell and the large one a fibroblast. $E$, Immunoblot analysis: 80 $\mu \mathrm{g}$ of cell extract $(C E)$ and $10 \times$ concentrated conditioned medium $(C M)$ from Schwann cell $(S C s)$ and sciatic nerve-derived fibroblast $(F b)$ cultures were loaded per lane. Purified rat PN-1 $(100 \mathrm{ng})$ was used as a reference. The arrowhead represents the location of the molecular weight standard ovalbumin $(42,7 \mathrm{kDa})$. Scale bar in $A, B, 10 \mu \mathrm{m}$; in $C, D, 16 \mu \mathrm{m}$.
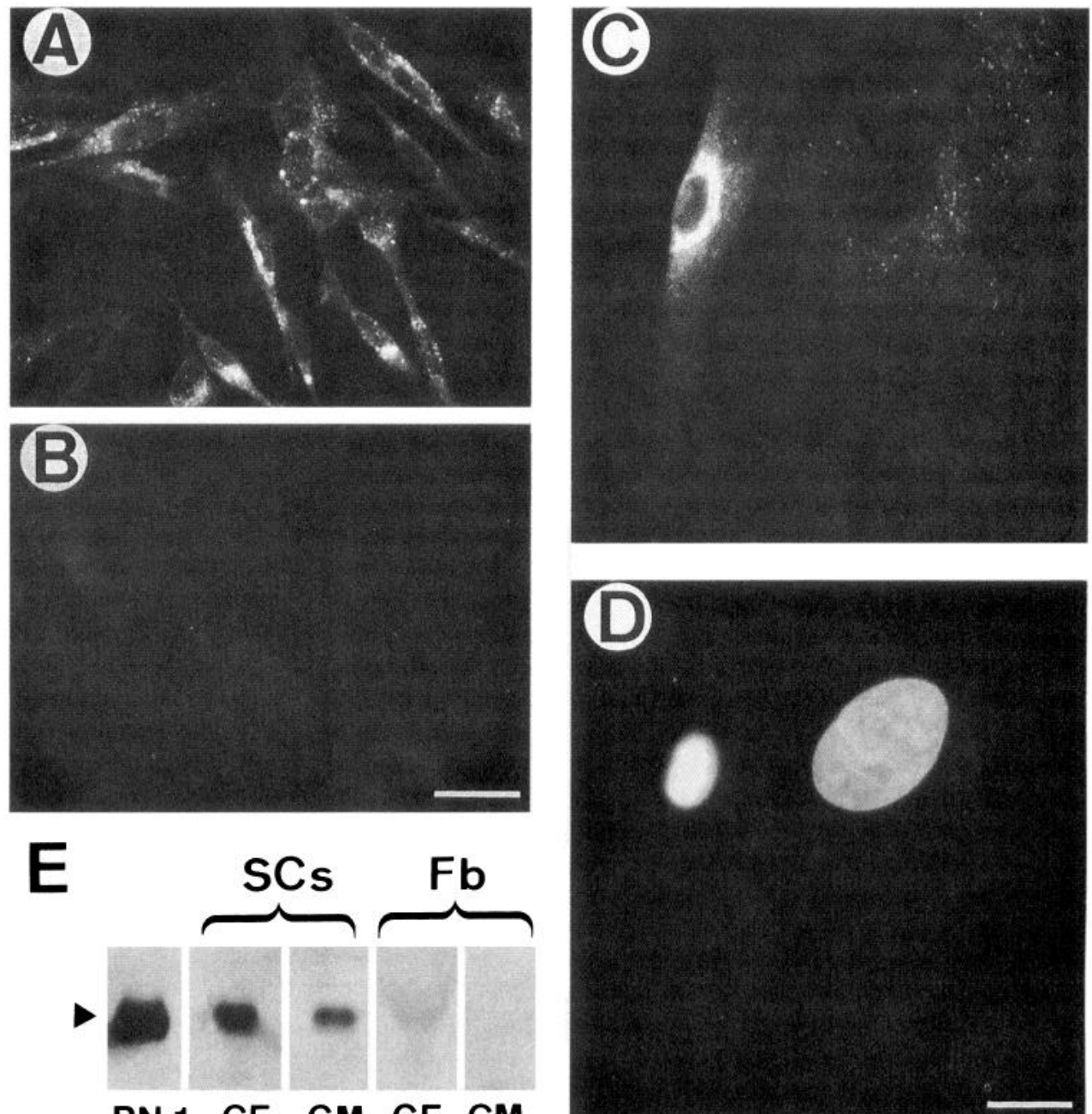

PN-1 CE CM CE CM

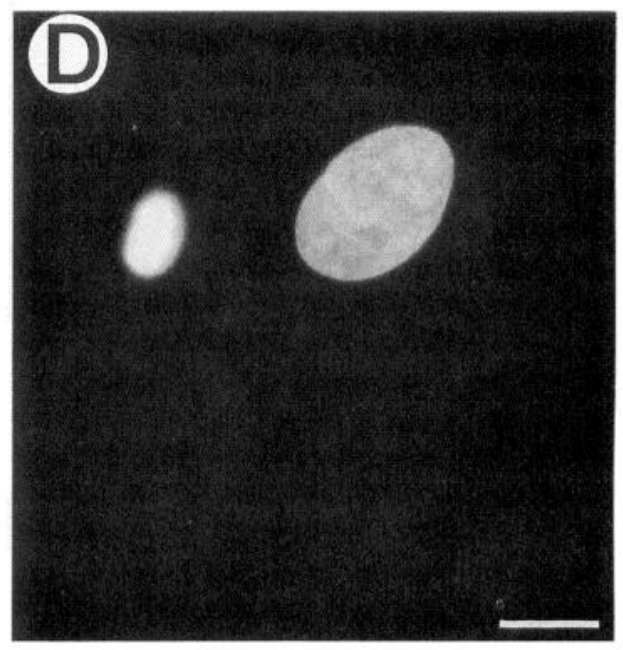

formed with the anti-PN-1 monoclonal antibody 4B3 showed bipolar-shaped positive cells, which were identified as Schwann cells by morphological criteria (Fig. $1 A, C$ ). In contrast to the in vivo studies, all these cells were both $\mathrm{PN}-1$ and $\mathrm{S} 100$ positive (data not shown). Occasional fibroblasts (3-5\%), easily identified by their large nucleus, showed weak staining (Fig. $1 C, D$ ). Immunoblot analysis confirmed these observations: while Schwann cell cultures synthesized high amounts of PN-1, only trace levels were found in cultures containing $97 \%$ of fibroblasts (Fig. 1E).

Using a sensitive ELISA assay, agents capable of modulating PN-1 synthesis were screened in primary cultures of Schwann cells. Potential candidates were substances known to be secreted by macrophages or to be regulated following nerve lesion (for reviews see Nathan, 1987; Fawcett and Keynes, 1990), including cytokines, mitogens, growth factors, and neurotrophic factors (Table 1). None of them influenced PN-1 synthesis with the exception of NGF, which caused a decrease in PN-1 mRNA levels after $9 \mathrm{hr}$ of treatment (data not shown). However, a marked effect was obtained only at high concentrations of NGF (above $100 \mathrm{ng} / \mathrm{ml}$ ) and could not be blocked by antiserum against NGF (Harlan Bioproducts For Science, Indianapolis, IN). In view of these facts, the presence of a contaminant could not be excluded. Since renin-like activity has been found in some NGF preparations (Otten et al., 1981), we investigated whether renin itself was responsible for the decrease in PN-1 mRNA levels.
Incubation of Schwann cell cultures with $50 \mathrm{ng} / \mathrm{ml}$ of recombinant renin showed that $\mathrm{PN}-1$ expression is transiently downregulated in a time-dependent manner (Fig. 2). A decrease of $23-26 \%$ was observed within the first $6-7 \mathrm{hr}$ of treatment. The maximal effect was reached at $9 \mathrm{hr}$ of incubation $(97 \%$ of reduction), and after this time point, PN-1 mRNA slowly increased, returning to basal levels after $24 \mathrm{hr}$ of renin application. It has been recently shown that a rapid decrease in Ang II receptor density $(90 \%$ within $30 \mathrm{~min})$ takes place via receptor internalization following incubation of neuroblastoma cells with Ang II (Reagan et al., 1993). This process of desensitization could thus explain why the effect caused by renin on PN-1 expression is observed only within a narrow time window.

Since the physiological role of renin is to initiate the production of the peptide hormone Ang II, the specificity of our initial observation was further examined by testing the effect of Ang II and Ang II antagonists in the regulation of PN-1 expression.

\section{The renin-angiotensin system and its involvement in $P N-1$ regulation}

The effector molecule of the renin-angiotensin system is the octapeptide Ang II, which originates from two successive proteolytic cleavages of the precursor protein angiotensinogen (AOGEN) by renin and the angiotensin-converting enzyme (ACE). Ang II mediates its effects through specific receptors 
Table 1. Factors that failed to modulate the expression of PN-1 in cultured Schwann cells

\begin{tabular}{|c|c|}
\hline Factors & Tested at \\
\hline \multicolumn{2}{|l|}{ Cytokines } \\
\hline IL-1 $\alpha$ & $10 \mathrm{ng} / \mathrm{ml}$ \\
\hline IL-1 $\beta$ & $10 \mathrm{ng} / \mathrm{ml}$ \\
\hline \multicolumn{2}{|l|}{ Mitogenic agents } \\
\hline 8Br-cAMP & $10^{-4} \mathrm{M}$ \\
\hline Forskolin & $2 \times 10^{-6} \mathrm{M}$ \\
\hline GGF & $20 \mathrm{ng} / \mathrm{ml}$ \\
\hline Myelin fraction & $200 \mathrm{ng} / \mathrm{ml}$ \\
\hline \multicolumn{2}{|l|}{ Macrophage-conditioned media } \\
\hline Not activated & $1: 1$ \\
\hline LPS activated & $1: 1$ \\
\hline PMA/ionomycin activated & $1: 1$ \\
\hline Myelin activated & $1: 1$ \\
\hline \multicolumn{2}{|l|}{ Growth factors } \\
\hline PDGF & $1 \mu \mathrm{Unit} / \mathrm{ml}$ \\
\hline Acidic FGF & $1,10 \mathrm{ng} / \mathrm{ml}$ \\
\hline Basic FGF & $0.1,1 \mathrm{ng} / \mathrm{ml}$ \\
\hline TGF $\beta$ & $2,10 \mathrm{ng} / \mathrm{ml}$ \\
\hline EGF & $10,90 \mathrm{ng} / \mathrm{ml}$ \\
\hline Phorbol ester & $1,10 \mathrm{ng} / \mathrm{ml}$ \\
\hline \multicolumn{2}{|l|}{ Neurotrophic factors } \\
\hline NGF & $1,10,20 \mathrm{ng} / \mathrm{ml}$ \\
\hline NT-3 & $1,10,50 \mathrm{ng} / \mathrm{ml}$ \\
\hline BDNF & $1,10 \mathrm{ng} / \mathrm{ml}$ \\
\hline CNTF & $0.1,1 \mathrm{ng} / \mathrm{ml}$ \\
\hline \multicolumn{2}{|l|}{ Neuroactive peptides } \\
\hline Substance P & $10^{-4}, 10^{-5} \mathbf{M}$ \\
\hline ANP & $10^{-6}, 10^{-7} \mathrm{M}$ \\
\hline Vasopressin & $10^{-7}, 10^{-8} \mathrm{M}$ \\
\hline CCK & $10^{-9}, 10^{-10} \mathbf{M}$ \\
\hline Somatostatin & $10,50 \mathrm{ng} / \mathrm{ml}$ \\
\hline Oxytocin & $100,500 \mathrm{ng} / \mathrm{ml}$ \\
\hline
\end{tabular}

After a culturing period of 8-10 d, primary Schwann cells were incubated for 24 and $48 \mathrm{hr}$ with the various agents under serum-free conditions, with exception of the macrophage-conditioned media containing serum. The concentrations used were chosen within the physiological range or according to the literature. Following these treatments, carried out in triplicate, the amounts of PN-1 secreted into the media were quantified by ELISA and normalized to the total amount of protein determined by the Bio-Rad assay. During the period of incubation, none of the various compounds showed toxic effects or induced significant changes in the morphology of the cells. IL-1, interleukin-1; GGF, glial growth factor; LPS, lipopolysaccharide; PMA, phorbol myristate acetate; PDGF, platelet-derived growth factor; FGF, fibroblast growth factor; TGF $\beta$, transforming growth factor $\beta$; EGF, epidermal growth factor, NGF, nerve growth factor, NT-3, neurotrophin-3; BDNF, brain-derived neurotrophic factor; CNTF, ciliary neurotrophic factor; ANP, atrial natriuretic peptide; $\mathrm{CCK}$, cholecystokinin.

located on the cell surface. Selective synthetic ligands are available for both Ang II receptor subtypes. Losartan (formerly DuP 753) binds to the subtype $\mathrm{AT}_{1}$, and CGP 42112 and PD 123319 to $\mathrm{AT}_{2}$ (reviewed by de Gasparo et al., 1992). The use of these compounds allows a selective displacement of Ang II as well as the discrimination of the receptor subtypes involved.

On the basis of this cascade, it was expected that Ang II would repress $\mathrm{PN}-1$ expression, and that $\mathrm{ACE}$ inhibitors as well as angiotensin antagonists may reverse the effect, which indeed proved to be the case. RNA samples were collected $9 \mathrm{hr}$ after treatment with the various compounds (Fig. $3 A$ ). The amounts

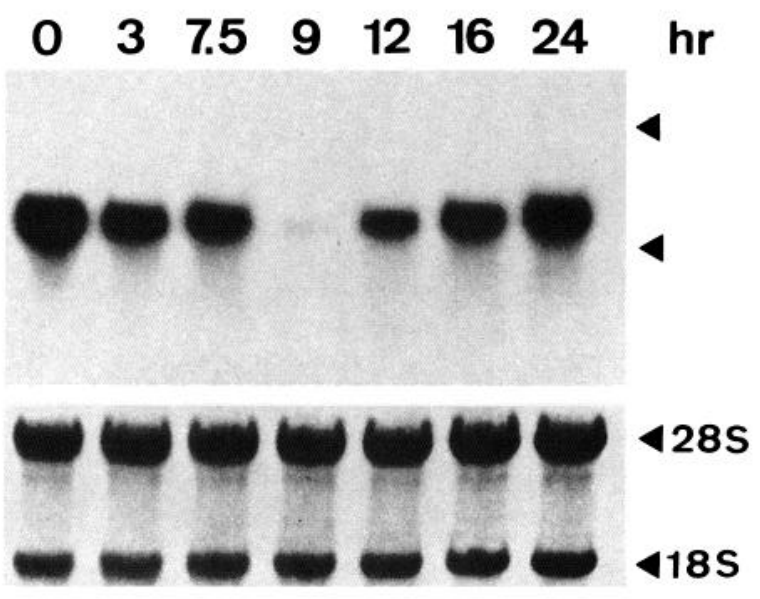

Figure 2. PN-1 expression is downregulated by renin in a time-dependent manner. Schwann cell cultures were incubated without (first lane) or with $50 \mathrm{ng} / \mathrm{ml}$ of renin under serum-free conditions for the indicated time. Northern blot analysis was performed using $5 \mu \mathrm{g}$ of total RNA extracted from these cultures. The autoradiogram was quantified by measuring the optical density at $400 \mathrm{~nm}$ using a Dual-wavelength TLC Scanner (Shimadzu). The obtained values, which were normalized taking the signal at zero time as $100 \%$ intensity, were $74 \%$ (after $3 \mathrm{hr}$ ), $77 \%$ (after $7.5 \mathrm{hr}$ ), 3\% (after $9 \mathrm{hr}$ ), 31\% (after $12 \mathrm{hr}$ ), 59\% (after $16 \mathrm{hr}$ ), and $79 \%$ (after $24 \mathrm{hr}$ ). Arrowheads indicate the position of the ribosomal RNAs, which were detected by methylene blue staining, as shown on the bottom.

of PN-1 protein secreted into the culture medium were measured after 9 and $24 \mathrm{hr}$ of treatment. Changes were apparent within $9 \mathrm{hr}$ (data not shown), but the response after $24 \mathrm{hr}$ was more remarkable (Fig. $3 B$ ). The delay between the maximal effect measured at the mRNA and protein level could be explained by the high stability of the PN-1 transcript (half-life of 8-10 hr in Schwann cells, data not shown), and/or by the stability of the protein in the conditioned medium. However, the changes detected in mRNA levels were consistently reflected in the amounts of synthesized and secreted protein. Ang II can mimic the downregulation of PN-1 expression caused by renin, although less efficiently (Fig. $3 A, B$ ). This could be explained by the high instability of this peptide. Indeed, about $70 \%$ of the Ang II added to the cultures was found to be degraded within the first $9 \mathrm{hr}$ of incubation (data not shown). As expected, when the ACE inhibitor enalapril was added together with renin, PN-1 levels remained unchanged. Interestingly, preincubation of the cultures with either of the receptor ligands, losartan or CGP 42112 , prior to Ang II addition not only prevented the decrease of PN-1 but triggered a severalfold upregulation over basal levels (Fig. 3A,B). The same effect was observed following treatment with losartan, CGP 42112, or PD 123319 alone, without subsequent administration of Ang II (data not shown). The large upregulation of PN-1 caused by these compounds could be due to the inhibition of active Ang II present in the cultures; evidence supporting an endogenous production of Ang II will be presented below. A permanent receptor occupancy by endogenously produced Ang II may lead to constitutive low production of PN1 ; receptor blockade may completely derepress the system, which then reaches much higher levels than basal.

Dose-response studies using losartan and CGP 42112 (Fig. $3 C)$ showed $\mathrm{PN}-1$ increase even at very low concentrations $\left(10^{-8}\right.$ M for losartan; $10^{-10} \mathbf{M}$ for CGP 42112). This would exclude the possibility of nonspecific cross-binding and support the idea of a mechanism potentially mediated by both $\mathrm{AT}_{1}$ and $\mathrm{AT}_{2}$ 
A
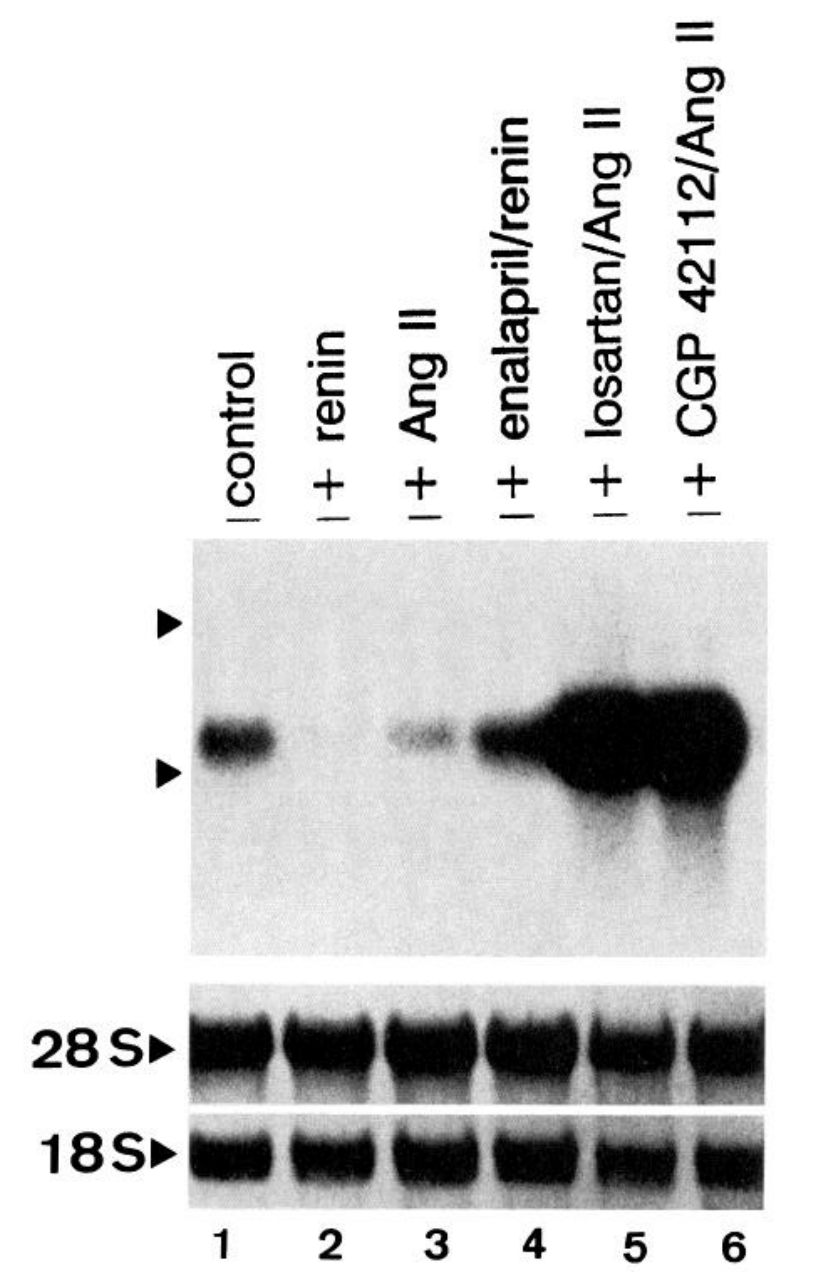

B

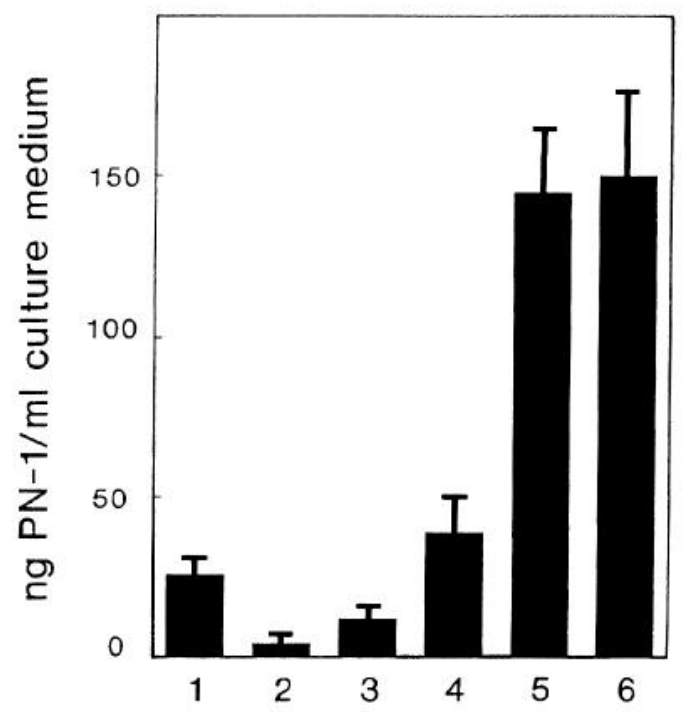

C

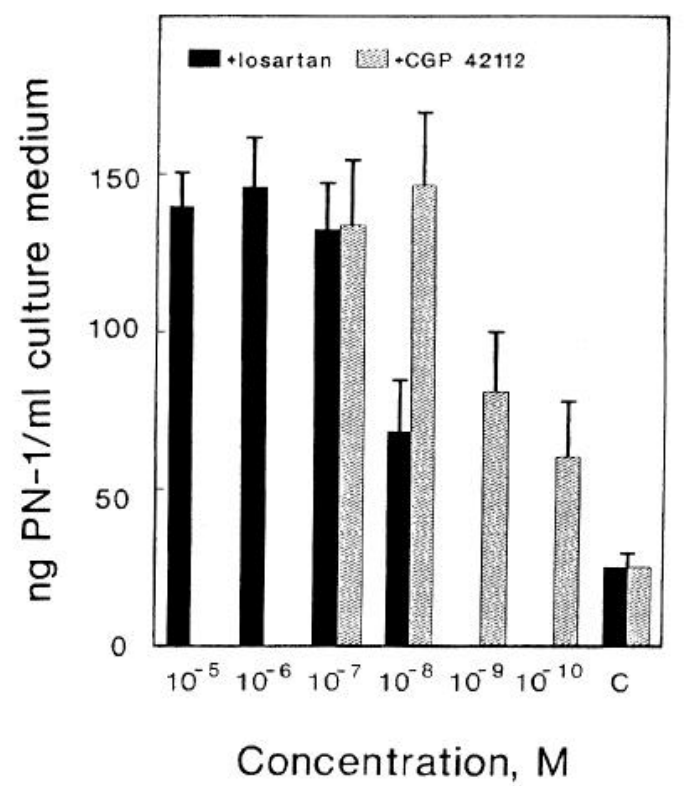

Figure 3. Angiotensin II decreases the level of PN-1 mRNA and protein, while the receptor ligands losartan and CGP 42112 strongly increase it. $A$, Northern blot analysis with $10 \mu \mathrm{g}$ total RNA from Schwann cell cultures treated with various compounds under serum-free conditions for 9 hr. Lane 1, untreated cells; lane 2, renin $(50 \mathrm{ng} / \mathrm{ml}=1.25 \mathrm{nM})$; lane 3, Ang II $(1 \mu \mathrm{M})$; lane 4 , renin $(50 \mathrm{ng} / \mathrm{ml})$ plus enalapril $(100 \mu \mathrm{g} / \mathrm{ml}=2.7 \mu \mathrm{M})$; lane 5, losartan (formerly DuP 753; $10 \mu \mathrm{M}$ ) plus Ang II; lane 6, CGP $42112(0.1 \mu \mathrm{M})$ plus Ang II. In lanes 5 and 6 , the receptor ligands were added $10 \mathrm{~min}$ before Ang II $(1 \mu \mathrm{M})$. Arrowheads indicate the position of the ribosomal RNAs (methylene blue staining shown on the bottom). B, Amounts of PN-1 protein secreted during $24 \mathrm{hr}$ by cultures treated as in $A$. Conditioned media were collected and the amount of secreted PN-1 was analyzed by ELISA. The values shown represent averages from three parallel dishes $\pm \mathrm{SD}$. $C$, Dose-response analysis with the selective ligands, losartan and CGP 42112, which bind to $\mathrm{AT}_{1}$ and $\mathrm{AT}_{2}$ receptors, respectively. As described above, cultures were incubated for 10 min with one or the other compound, followed by addition of Ang II $(1 \mu \mathrm{M})$. Changes in the amounts of secreted PN-1 after a 24 hr treatment were analyzed by ELISA. $c$, control levels of untreated cells. The illustrated values represent averages of three dishes \pm SD.

receptor subtypes. Although CGP 42112 caused effects analogous to those of losartan in PN-1 expression, it remained to be determined whether in our system the peptide CGP 42112 was acting as an $\mathrm{AT}_{2}$ antagonist or as an agonist, as described for NG108-15 neuroblastoma, PC-12W, and COS cells transfected with the $\mathrm{AT}_{2}$-cDNA (Buisson et al., 1992; Brechler et al., 1993; Kambayashi et al., 1993). To clarify this aspect, we treated Schwann cell cultures with the nonpeptidic $\mathrm{AT}_{2}$ antagonist PD 123319. This resulted in a large induction of $\mathrm{PN}-1$ as well (data not shown), suggesting that CGP 42112 would act in this type 
A

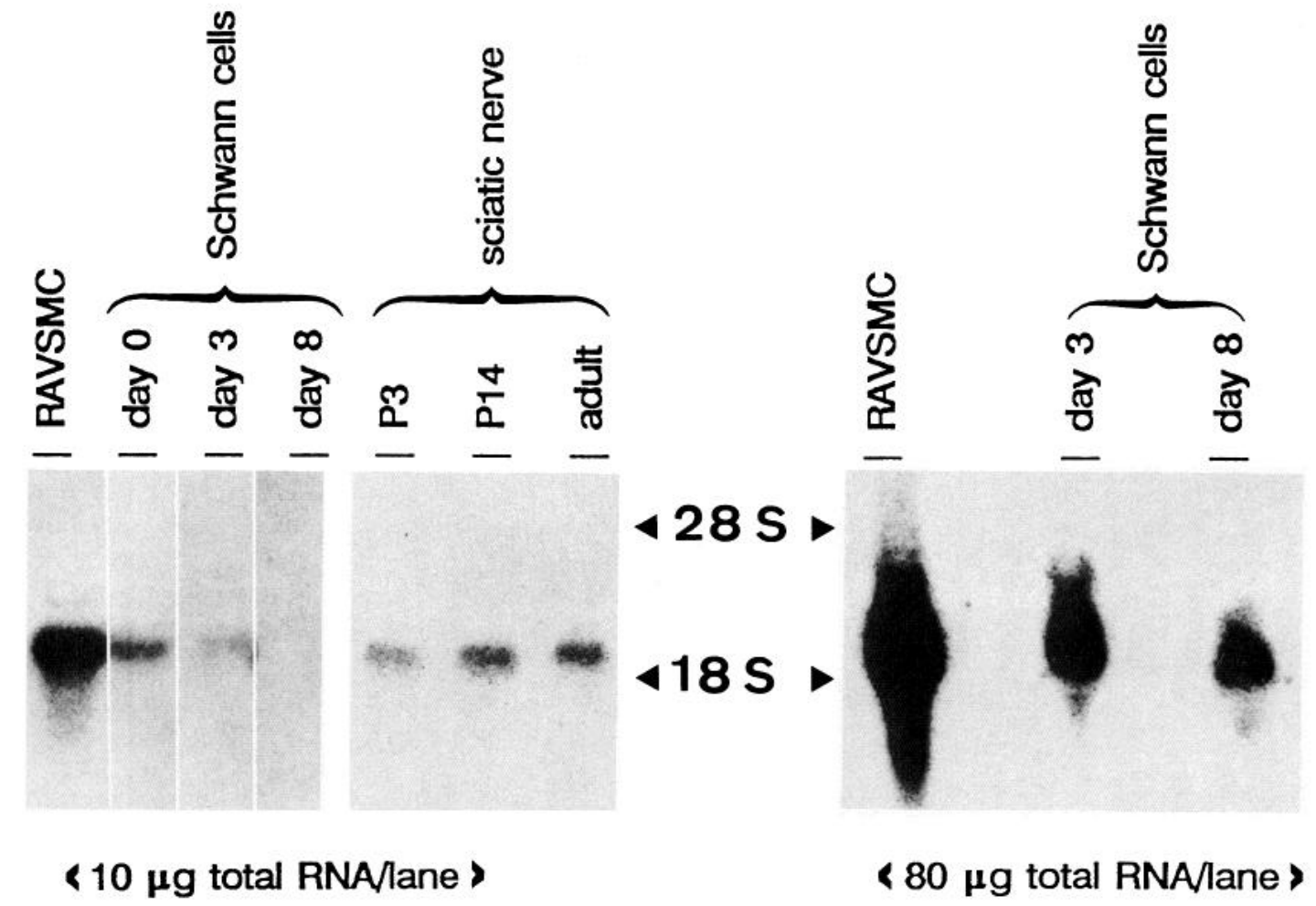

B

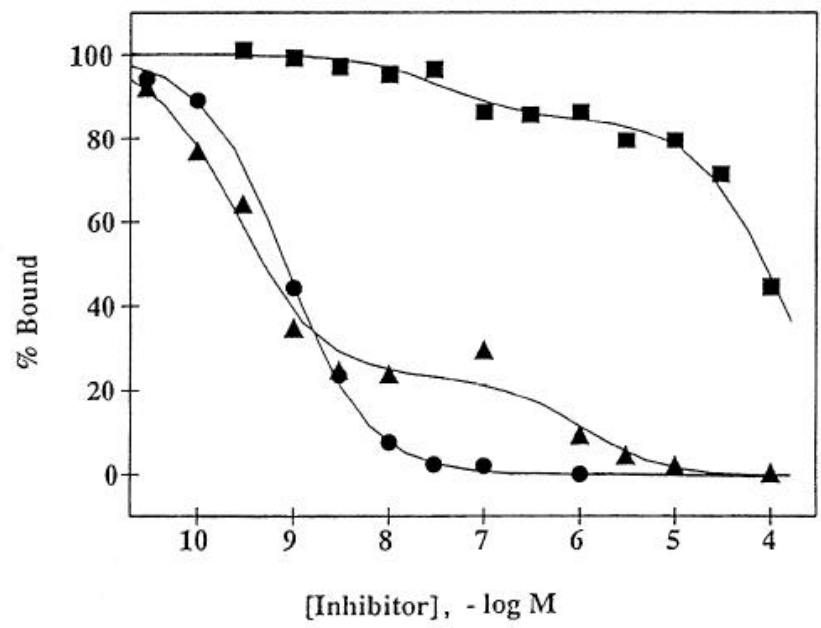

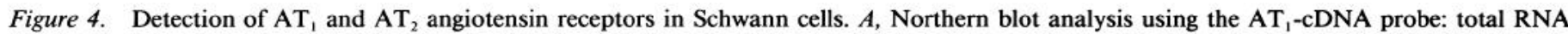
was isolated from Schwann cell cultures as well as from undissociated tissue. Cultures of rat aortic vascular smooth muscle cells $(R A V S M C)$ were used as positive control; Schwann cells prepared by dissociation of sciatic nerves $(P 3)$ were kept in culture for 0,3 , or $8 \mathrm{~d}$. Detection of AT -mRNA $^{-m}$ in sciatic nerves from P3, P14, and adult animals indicates that the receptor is also expressed in vivo. The amount of total RNA analyzed per lane is indicated at the bottom. Arrowheads show the position of the ribosomal RNAs. B, Angiotensin binding studies using selective AT, and AT 2 ligands: membrane fractions were prepared from Schwann cell cultures harvested $20 \mathrm{hr}$ after enzymatic dissociation. They were then incubated with ${ }^{125}$ I-Ang II in the presence of unlabeled Ang II (๑), losartan (AT, selective; $\square$ ), or CGP 42112 (AT, selective; $\boldsymbol{\Delta}$ ) at various concentrations. Scatchard analysis of the Ang II competition curve gave the following binding constants: $B_{\max }=98.3 \mathrm{fmol} / \mathrm{mg} K_{d}=0.63 \mathrm{nM} ; \mathrm{ratio} \mathrm{AT}, / \mathrm{AT}_{2}=$ 20/80.

of cells similarly to PD 123319 , namely by blocking $\mathrm{AT}_{2}$ receptors. This apparent paradox could be due to different $\mathrm{AT}_{2}$ receptor isoforms, as described by Tsutsumi and Saavedra (1991b) in the rat brain.

Experiments identical to those shown in Figure 3 were per- formed on fibroblast-enriched cultures, but none of the treatments affected PN-1 synthesis (data not shown). Therefore, it is very unlikely that the $3-5 \%$ of fibroblast contamination in the Schwann cell cultures would significantly contribute to the observed PN-1 modulation by the various compounds. 

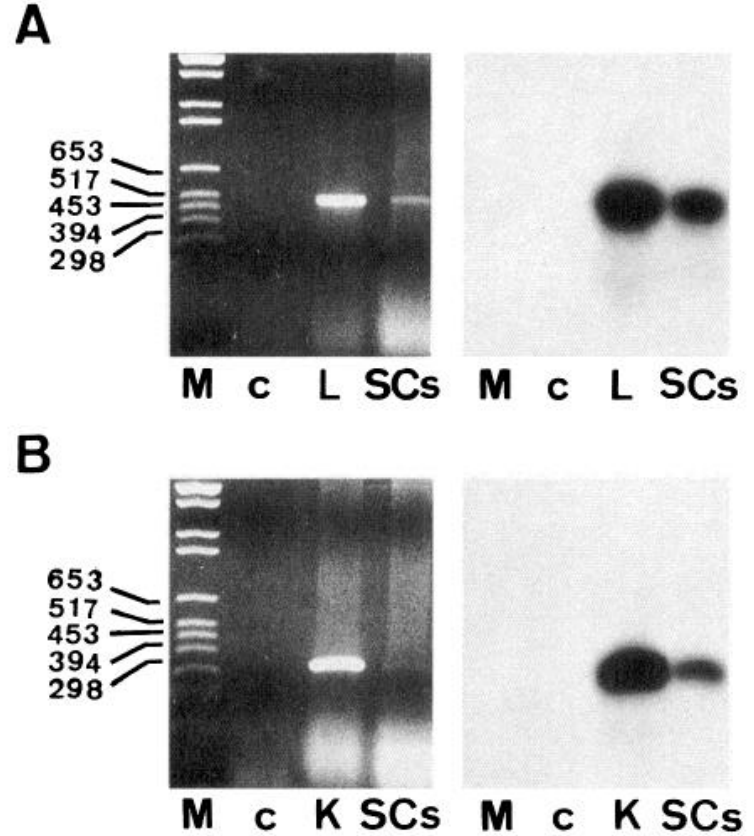

Figure 5. Detection of AOGEN- and renin-mRNA in Schwann cell cultures by RT-PCR. Total RNA $(2 \mu \mathrm{g})$ from rat liver $(L)$, kidney $(K)$, and cultured Schwann cells ( $S C s$ ) was reverse transcribed as described in Materials and Methods. The obtained cDNAs were amplified by PCR and their identity confirmed by Southern blot analysis. $M$, DNA molecular weight marker VI (Boehringer); $c$, negative control (reaction mix minus RNA template). $A$, Amplification of the AOGEN-mRNA; the primers are located at nucleotides 1005-1025 (sense) and 1489-1509 (antisense). A single product of 504 bp was obtained, as shown in the ethidium bromide-stained gel (left) and in the corresponding autoradiogram (right). B, Amplification of the renin-mRNA; the primers are located at nucleotides 925-945 (sense) and 1242-1262 (antisense). A single product of $337 \mathrm{bp}$ was obtained, as shown in the ethidium bromide-stained gel (left) (note the faint band present on the SCs lane) and in the corresponding autoradiogram (right).

\section{Detection and characterization of Ang II receptors in Schwann cells}

While specific angiotensin receptors were found on neuronal cells and astrocytes (reviewed by Sumners et al., 1990), their presence had not yet been reported on Schwann cells. We performed Northern blot analysis using the $\mathrm{AT}_{1}$-cDNA probe (Fig. $4 A$ ). For this purpose, total RNA was isolated from cultured Schwann cells as well as from fresh undissociated rat sciatic nerves at various developmental stages. Since the $\mathrm{AT}_{\text {, }}$ receptor subtype is highly expressed by aortic vascular smooth muscle cells (Whitebread et al., 1989), their RNA was used as positive control. The band detected on the autoradiogram corresponds to the $2.3 \mathrm{~kb}$ transcript previously described by Murphy et al. (1991). Expression of the AT - mRNA in Schwann cells is drastically reduced during increasing time in culture $(0-8 \mathrm{~d})$. In fact, to clearly detect the transcript in cells cultured for 3 and $8 \mathrm{~d}$, we had to perform Northern blot analysis with up to $80 \mu \mathrm{g}$ of total RNA per lane. $\mathrm{AT}_{1}$-mRNA was present in the sciatic nerve in vivo at various developmental stages (postnatal day 3, 14, and adult) (Fig. 4A).

A further characterization of Ang II receptors was undertaken by Ang II binding studies. The following assays were performed using membrane fractions prepared from Schwann cells kept in culture for a short period of time: cells were allowed to recover from the enzymatic dissociation and harvested $20-24 \mathrm{hr}$ after plating, when $A T_{\text {, }}$ receptor expression was expected to be the highest, according to the results shown in Figure $4 A$. Since such assays require a high number of primary Schwann cells, the curves shown in Figure $4 B$ illustrate single measurements; however, similar values were obtained with other membrane preparations tested in independent experiments. Competition curves with unlabeled Ang II were used to estimate the binding constants: total concentration of binding sites $\left(B_{\max }\right)=79.2 \mathrm{fmol} /$ $\mathrm{mg}$ protein and the dissociation constant $\left(K_{d}\right)=0.75 \mathrm{~nm}$ (means of two determinations). These values are comparable to those described for neuronal and astrocytic cultures (Sumners et al., 1990). In addition, no detectable receptor levels were found using membrane fractions of fibroblast-enriched cultures (data not shown). Incubation with the ligand Ang (1-6) showed no binding displacement (data not shown), indicating an absence of mycoplasma contamination, a potential source of Ang II receptors in cell cultures (Whitebread et al., 1993).

The proportions of Ang II receptor subtypes were $17 \% \mathrm{AT}_{1}$ and $83 \% \mathrm{AT}_{2}$ (means of two determinations), as estimated from the competition curves of losartan ( $\mathrm{AT}_{1}$ selective) and CGP 42112 ( $\mathrm{AT}_{2}$ selective). It thus appears that $\mathrm{AT}_{2}$ represents the majority of the angiotensin receptors present on freshly plated Schwann cells. However, it must be borne in mind that this ratio could change during time in culture, as reported for other cell types (reviewed by de Gasparo et al., 1992). Binding assays performed with sciatic nerve membranes of P14 and adult animals confirmed the presence of both receptor subtypes also in vivo. The ratio $\mathrm{AT}_{1} / \mathrm{AT}_{2}$ consisted of about $45 / 55$ and $90 / 10$, respectively (data not shown), indicating notable changes in the expression of both receptor subtypes during development, as previously described in other tissues (Tsutsumi and Saavedra, 1991a).

\section{Evidence for Ang II production in Schwann cell cultures}

The information about the production of components of the renin-angiotensin system in cells of the nervous system is fragmentary, mainly because the amounts synthesized are extremely low compared to liver, kidney, or blood, and thus require more sensitive detection methods. In addition, the existence of alternative enzymatic pathways has been recently postulated (reviewed by Ferrario et al., 1990). However, transcripts of the precursor protein and of various enzymes potentially involved in Ang II generation are widespread in the brain (reviewed by Bunnemann et al., 1991).

The presence of Ang II in the serum-free conditioned medium of Schwann cells has been measured according to the radioimmunoassay described by Nussberger and colleagues (1985), but omitting the HPLC purification. Interestingly, although small amounts of Ang II were released by these cultures $(4.22 \pm 0.24$ $\mathrm{fmol} / \mathrm{ml}, n=3$ ), 29 -fold higher levels were detected following incubation with renin for $9 \mathrm{hr}(125 \mathrm{fmol} / \mathrm{ml})$ (data not shown). Moreover, these preliminary results also show that the Ang II production by Schwann cell cultures was stimulated in a timedependent manner upon renin treatment, becoming less pronounced after 16 or $24 \mathrm{hr}$ ( 57 and $49 \mathrm{fmol} / \mathrm{ml}$, respectively) (data not shown). It is worth noticing that the same $9 \mathrm{hr}$ of incubation are required to obtain the maximal inhibition of PN-1 mRNA expression. Since high amounts of AOGEN and prorenin are, however, present in the serum-containing cultures previous to the change to serum-free conditions, the existence of an endogenous renin-angiotensin system had to be confirmed using another strategy. We therefore tested whether the mRNA 
transcripts of AOGEN and renin, the only proteins exclusively involved in the production of Ang II, are present in Schwann cell cultures. For this purpose, RT-PCR was performed, taking as positive controls liver and kidney, the main sources of AOGEN and renin, respectively. The results are summarized in Figure 5 . The size of the RT-PCR products obtained corresponds to the expected fragments, namely, 504 bp for AOGEN (Fig. 5A) and $337 \mathrm{bp}$ for renin (Fig. $5 B$ ); their identity was confirmed by Southern blot analysis using the corresponding rat AOGENand renin-cDNA probes (Fig. $5 A, B$ ). Further experiments using primers selected to amplify another region of the AOGEN- or renin-cDNA showed a single specific product as well (data not shown). Similar results have been obtained by RT-PCR performed with RNA extracted from fibroblast-enriched cultures and the schwannoma cell line $\mathrm{P}_{2} \mathrm{~T}$ (data not shown). Therefore, and since the PCR can amplify even single molecules of mRNA transcript, it remains to be determined whether Schwann cells, fibroblasts, or both cell types produce Ang II in these primary cultures. However, since Schwann cells and fibroblasts are also in close contact in vivo, our results support the possibility of an endogenous renin-angiotensin system acting in an autocrine and/ or paracrine manner.

\section{Cell type-specific regulation of protease inhibitors by Ang II}

Olson and colleagues (1991) have recently shown that treatment of cultured astrocytes with Ang II increases the secretion of the protease inhibitor plasminogen activator inhibitor-1 (PAI-1) and of a tissue metalloprotease inhibitor-related protein (hTIMP) in a coordinated way. Since the opposite regulatory pattern is found for PN-1 in Schwann cells, we investigated how PAI-1, as another example of a protease inhibitor, would be affected by Ang II in these cells.

Northern blot analysis showed that PAI-1 mRNA levels are regulated in Schwann cells in a fashion similar to that of PN1: while renin and Ang II repressed expression, Ang II antagonists induced it (Fig. 6). The two mRNA bands detected on the autoradiogram correspond to the 2.4 and $3.4 \mathrm{~kb} \mathrm{PAI}-1$ transcripts previously described by Lund et al. (1987). Ang II did not significantly influence PN-1 expression when added to astrocytic cultures prepared from neonatal rats (data not shown). PAI-1 secretion was also found to be affected only in cultured astrocytes derived from 21-d-old rats (Olson et al., 1991). Further investigation should define the regulatory effect of Ang II on PN-1 synthesis in such cultures. In summary, this data indicates that Ang II regulates the expression of various protease inhibitors in a coordinated way but in a cell type-specific manner. An opposite regulation in different cell types has in fact already been shown following injury of the blood vessel wall, where Ang II decreases the secretion of the protease u-PA in endothelial cells but increases it in smooth muscle cells (Bell and Madri, 1990).

\section{Effect of other neuroactive peptides on $\mathrm{PN}-1$ expression}

In addition to Ang II, among the peptides tested (see Table 1), only CGRP and VIP affected PN-1 expression (Fig. 7). While CGRP repressed mRNA and protein levels, VIP acted as a positive regulator of $\mathrm{PN}-1$ synthesis. This finding is in fact in agreement with previous observations of Brenneman and coworkers (1987), that VIP increases the secretion of glia-derived neurotrophic factors in astrocytic cultures. In comparison to Ang II, a longer incubation with CGRP and VIP was required

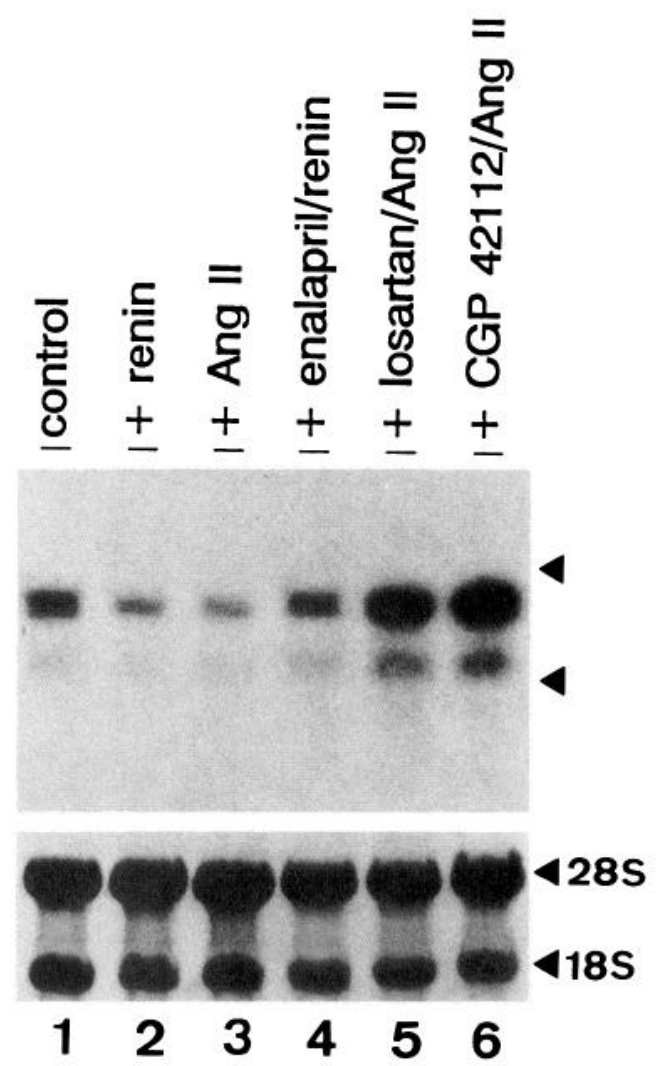

Figure 6. Ang II causes downregulation of PAI-1 expression in Schwann cells. Northern blot analysis was performed with $10 \mu \mathrm{g}$ of total RNA of the same samples used in Figure 3. Lane 1, untreated cells; lane 2, renin $(50 \mathrm{ng} / \mathrm{ml}=1.25 \mathrm{~nm})$; lane 3, Ang II $(1 \mu \mathrm{M})$; lane 4 , renin $(50 \mathrm{ng} / \mathrm{ml})$ plus enalapril $(100 \mu \mathrm{g} / \mathrm{ml}=2.7 \mu \mathrm{M}$ ); lane 5 , losartan (formerly DuP 753; $10 \mu \mathrm{M})$ plus Ang II; lane 6, CGP $42112(0.1 \mu \mathrm{M})$ plus Ang II. The signals correspond to the 2.4 and $3.4 \mathrm{~kb}$ PAI- 1 transcripts. Arrowheads indicate the position of the ribosomal RNAs (methylene blue staining shown on the bottom).

to obtain a maximal effect $(24 \mathrm{hr}$ at the mRNA and $36 \mathrm{hr}$ at the protein level) (Fig. 7).

\section{Discussion}

The present study shows that Ang II, CGRP, and VIP differentially modulate the synthesis of PN-1 in cultured Schwann cells, indicating that changes triggered by neuropeptides could result in a local modulation of the extracellular proteolytic activity. None of a large number of injury-associated factors was able to regulate PN-1 expression in primary Schwann cell cultures. It is particularly surprising that IL-1 remained without effect in view of it having been reported to upregulate the expression of PN-1 in cultured skin fibroblasts and the SK-N-SH neural cell line (Guttridge et al., 1993; Vaughan and Cunningham, 1993). It is, however, worth mentioning that IL-1 induced the synthesis of NGF in the sciatic nerve (Heumann et al., 1987; Lindholm et al., 1987) but failed to do so in Schwann cell cultures (Matsuoka et al., 1991). Furthermore, TGF $\beta$ and PDGF, which cause increased PN-1 synthesis in these SK-N-SH cells (Vaughan and Cunningham, 1993), did not influence it in cultured Schwann cells. It seems, therefore, that the mechanisms regulating $\mathrm{PN}-1$ expression differ markedly among the various cell types, as has been previously described for NGF. The upregulation of NGF in fibroblasts is mediated by IL-1, but in the 

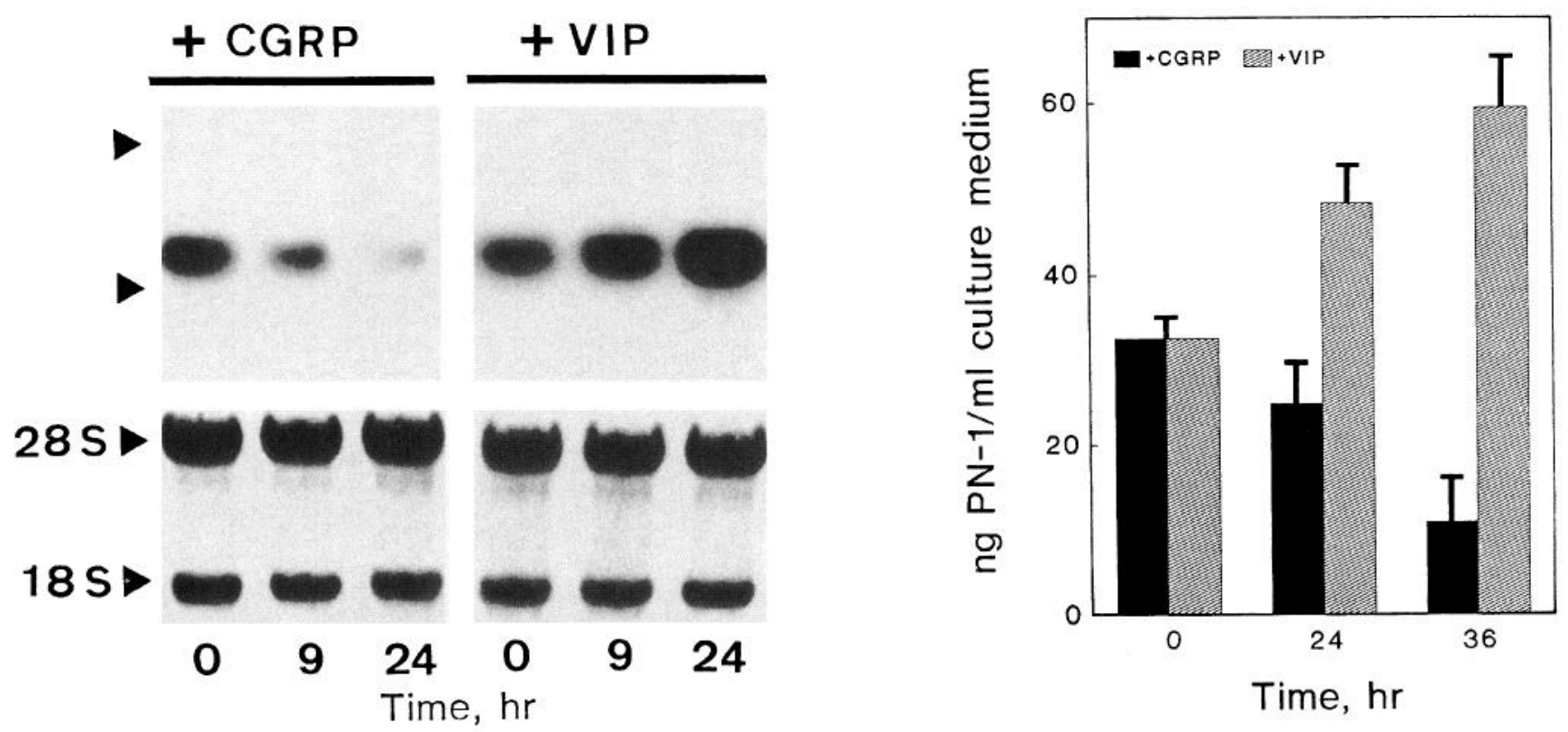

Figure 7. Expression of PN-1 is downregulated by CGRP but upregulated by VIP. PN-1 mRNA and protein levels were analyzed following incubation of Schwann cell cultures with CGRP $(0.1 \mu \mathrm{M})$ or VIP $(0.1 \mathrm{nM})$. For Northern blot analysis $(A)$, cells were harvested after 9 and $24 \mathrm{hr}$ of treatment. Arrowheads indicate the position of the ribosomal RNAs, visualized by methylene blue staining $($ bottom). Conditioned media were collected after 24 and $36 \mathrm{hr}$ of treatment and tested by ELISA $(B)$. The illustrated values represent averages of three dishes \pm SD.

case of Schwann cells, by drugs like forskolin which raise intracellular levels of cAMP (Matsuoka et al., 1991). It was worth noticing as well that TGF $\beta$ treatment did not influence PN-1 synthesis, since it has recently been described as enhancing the secretion of PAI-1 by cultured adult rat Schwann cells (Rogister et al., 1993); however, this result is not too surprising as PN-1 and PAI-1 were shown to have different expression pattern (Sappino et al., 1993).

An important event during peripheral nerve regeneration is the activation of Schwann cell proliferation, which reaches the highest rate within 3-5 d (Pellegrino et al., 1986). As the maximal induction of $\mathrm{PN}-1$ takes place only shortly thereafter, namely 6-7 d following nerve injury (Meier et al., 1989), it is interesting to note that agents mitogenic for Schwann cells do not influence the levels of PN-1 synthesized, at least under the culture conditions used here.

\section{An endogenous renin-angiotensin system regulates $P N-1$ expression in cultured Schwann cells}

Treatment of Schwann cell cultures with renin or Ang II represses PN-1 mRNA and protein levels. This downregulation can be specifically reversed by Ang II antagonists in a dosedependent manner. At this stage, we do not know whether the effects observed result from changes in transcription rate or in the stability of PN-1 mRNA. However, the correlation we find between the amount of PN-1 mRNA and protein suggests that modifications in the efficiency of translation are unlikely to be a major mechanism in $\mathrm{PN}-1$ regulation. In addition, Ang II, endogenously produced by these cell cultures, may regulate $\mathrm{PN}-1$ synthesis in an autocrine-paracrine way. Moreover, this endogenous renin-angiotensin system appears to similarly affect the expression of PAI-1, another protease inhibitor.
Our results indicate that the basal level of $\mathrm{PN}-1$ in untreated cells may reflect a semirepressed state, resulting from a constitutive but partial occupancy of Ang II receptors. The addition of Ang II may then lead to activation of all the receptors and therefore to maximal repression of $\mathrm{PN}-1$ synthesis. On the other hand, maximal production of $\mathrm{PN}-1$ was reached following Ang II displacement using losartan, CGP 42112, or PD 123319. Interestingly, blocking only one receptor subtype was enough to obtain maximal PN-1 derepression. A simultaneous activation of $\mathrm{AT}_{1}$ and $\mathrm{AT}_{2}$ receptors might thus be required for the repression of PN-1. This would suggest that both receptor subtypes trigger distinct but ultimately converging intracellular pathways, the activation of only one of them being insufficient. Indeed, previous studies support the idea that some cellular responses triggered by Ang II may be simultaneously mediated by both receptor subtypes and that a balance in their regulation may exist (de Gasparo et al., 1992; Zarahn et al., 1992). Since astrocytes contain only $\mathrm{AT}_{1}$ and Schwann cells both receptor subtypes, an unequal receptor composition could possibly account for the differential effects caused by Ang II on the PAI-1 expression in these two types of cells. Obviously, potential interactions between both receptor subtypes should be further investigated.

\section{Possible role of Ang II receptors in Schwann cells}

The existence of $\mathrm{AT}_{1}$ and $\mathrm{AT}_{2}$ receptor subtypes on Schwann cells is demonstrated here for the first time by Northern blot analysis and Ang II binding studies. Three main pieces of evidence suggest that the described Ang II binding sites are likely to be physiological receptors for Ang II. First, the measured binding of ${ }^{125} \mathrm{I}$-Ang II to the membrane preparation was saturable and of high affinity $\left(K_{d}=0.75 \mathrm{~nm}\right)$. Second, the effect of 
Ang II on intact cells was specifically blocked in a dose-dependent manner by selective ligands. Third, the receptors were found not only in cultured cells, but also in fresh biopsy of rat sciatic nerve, where the ratio $\mathrm{AT}_{1} / \mathrm{AT}_{2}$ showed strong differences between young and adult animals. In the brain, maximal $\mathrm{AT}_{2}$ levels were found during embryonic and early postnatal stages. It has been postulated, therefore, to be involved in various developmental processes (Tsutsumi and Saavedra, 1991a; Mukoyama et al., 1993). The expression of $\mathrm{AT}_{2}$ receptors was shown to be strongly regulated also during differentiation of neuroblastoma cells and wound healing (reviewed by Tallant et al., 1991; de Gasparo et al., 1992). Finally, the presence on Schwann cells of more than one receptor subtype would support the possibility of distinct intracellular changes in response to Ang II. In this context, whether the ratio of $\mathrm{AT}_{1} / \mathrm{AT}_{2}$ plays a role in the way Ang II modulates PN-1 expression remains to be investigated. It also remains to be seen if the downregulation of Ang II receptors observed here with time in culture could have some physiological relevance for the regulation of $\mathrm{PN}-1$ in vivo.

These results indicate that it is possible that other types of receptors could also be downregulated with time in culture. It is therefore not excluded that one or the other of the injuryassociated substances could have influenced PN-1 synthesis if tested at different stages of the culture.

\section{Neuropeptides as mediators of neuron-glia interactions}

Many neuropeptides are considered to mediate diverse interactions between neurons and glial cells (Gozes and Brenneman, 1989; Bunneman et al., 1991; Dumoulin et al., 1992). However, the mode of action of Ang II, CGRP, and VIP in the nervous system is poorly understood. The studies aimed to characterize their neurotrophic properties indicate that the responses induced in neuronal cells require the presence of glial cells (Brenneman et al., 1987; Iwasaki et al., 1991). Indeed, functional binding sites for a variety of neuroactive peptides including VIP, calcitonin, somatostatin, and substance $P$ have been described on astrocytes and Schwann cells (for reviews see Villegas et al., 1988; Wilkin and Cholewinski, 1988). Together with the studies mentioned previously (Brenneman et al., 1987; Bell and Madri, 1990; Olson et al., 1991), our results confirm and point out the high diversity in the potential of neuropeptides to modulate the proteolytic activity in the microenvironment by regulating the amounts of secreted proteases and protease inhibitors.

Numerous studies have shown that the expression of various neuropeptides, including VIP and CGRP, is modulated following axotomy of the sciatic nerve. While VIP levels are increased in sensory and motor neurons (Shehab and Atkinson, 1986; Villar et al., 1989; Doughty et al., 1991), CGRP levels are differentially regulated in these distinct neuronal populations. CGRP immunoreactivity is increased in motoneurons but it is decreased in sensory neurons of the dorsal root ganglia (Noguchi et al., 1990; Doughty et al., 1991; Dumoulin et al., 1992). Sensory fibers are most likely responsible for $95 \%$ of the axonally transported CGRP in the intact sciatic nerve, and, in fact, the anterograde axonal transport of CGRP decreases to $40-50 \%$ of control values 6-8 d after lesion (Raivich et al., 1992). It is therefore plausible that the lesser amounts of CGRP synthesized by sensory neurons may lead to a lower level of the peptide in the injured nerve. Whether a direct relationship exists between these mechanisms and the induction of $\mathrm{PN}-1$ observed after injury (Meier et al., 1989) remains to be investigated. Further- more, neither the regulation of Ang II nor the regulation of Ang II receptors following nerve lesion is yet known.

Our data are, nevertheless, consistent with the idea that neuropeptides produced by neuronal cells may cause modulation of PN-1 secretion by Schwann cells. For instance, it is conceivable that peptides such as Ang II and CGRP released by intact neurons would strongly downregulate PN-1 synthesis and that nerve injury would interrupt this negative control, allowing Schwann cells to react by default by the production of PN-1. By contrast, increased amounts of secreted VIP following lesion could enhance this effect. Alternatively, neurons could repress $\mathrm{PN}-1$ synthesis by releasing molecules able to modulate the levels of endogenous Ang II and Ang II receptors in surrounding non-neuronal cells. Obviously, further detailed in vivo studies will be required to establish the physiological relevance of the neuropeptide-mediated regulation of $\mathrm{PN}-1$ synthesis following nerve lesion.

\section{References}

Baichwal RR, Bigbee JW, DeVries GH (1988) Macrophage-mediated myelin-related mitogenic factor for cultured Schwann cells. Proc Natl Acad Sci USA 85:1701-1705.

Bell L, Madri JA (1990) Influence of the angiotensin system on endothelial and smooth muscle cell migration. Am J Pathol 137:7-12.

Brechler V, Jones PW, Levens NR, de Gasparo M, Bottari SP (1993) Agonistic and antagonistic properties of angiotensin analogs at the $\mathrm{AT}_{2}$ receptor in PC-12 cells. Regul Pept 44:207-213.

Brenneman DE, Neale EA, Foster GA, d'Autremont SW, Westbrook GL (1987) Non-neuronal cells mediate neurotrophic action of vasoactive intestinal peptide. J Cell Biol 104:1603-1610.

Brockes JP, Fields KL, Raff MC (1979) Studies on cultured rat Schwann cells. Establishment of purified populations from cultures of peripheral nerve. Brain Res 165:105-118.

Buisson B, Bottari SP, de Gasparo M, Gallo-Payet N, Payet MD (1992) The angiotensin $\mathrm{AT}_{2}$ receptor modulates T-type calcium current in non-differentiated NG108-15 cells. FEBS Lett 309:161-164.

Bunnemann B, Fuxe K, Bjelke B, Ganten D (1991) The brain reninangiotensin system and its possible involvement in volume transmission. In: Volume transmission in the brain: novel mechanisms for neuronal transmission (Fuxe K, Agnati LF, eds), pp 131-158. New York: Raven.

Chomczynski P, Sacchi N (1987) Single-step method of RNA isolation by acid guanidium thiocyanate-phenol-chloroform extraction. Anal Biochem 162:156-159.

De Gasparo M, Whitebread S, Levens N, Ramjoué HP, Criscione L, Rogg H, Baum HP, Brechler V, Buehlmayer P, Wood JM, Bottari SP (1992) Pharmacology of angiotensin II-receptor subtypes. In: Cellular and molecular biology of the adrenal cortex (Saez JM, Brownie AC, Capponi A, Chambaz EM, Mantero F, eds), pp 3-17. Colloque INSERM: Libbey.

Doughty SE, Atkinson ME, Shehab SA (1991) A quantitative study of neuropeptide immunoreactive cell bodies of primary afferent sensory neurons following rat sciatic nerve peripheral axotomy. Regul Pept 35:59-72.

Dumoulin FL, Raivich G, Haas CA, Lazar P, Reddington M, Streit WJ, Kreutzberg GW (1992) Calcitonin gene-related peptide and peripheral nerve regeneration. Ann NY Acad Sci 657:351-360.

Fawcett JW, Keynes RJ (1990) Peripheral nerve regeneration. Annu Rev Neurosci 13:43-60.

Ferrario CM, Barnes KL, Block CH, Brosnihan BK, Diz DI, Khosla MC, Santos RA (1990) Pathways of angiotensin formation and function in the brain. Hypertension 15/I:13-19.

Festoff BW, Rao JS, Rayford A, Hantai D (1990) Plasminogen activators and their inhibitors in the neuromuscular system: II. Serpins and serpin: protease complex receptors increase during in vitro myogenesis. J Cell Physiol 144:272-279.

Gloor S, Odink K, Guenther J, Nick HP, Monard D (1986) A gliaderived neurite promoting factor with protease inhibitory activity belongs to the protease nexins. Cell 47:687-693.

Gozes I, Brenneman DE (1989) VIP: molecular biology and neurobiological function. Mol Neurobiol 3:201-236. 
Gressens P, Hill JM, Gozes I, Fridkin M, Brenneman DE (1993) Growth factor function of vasoactive intestinal peptide in whole cultured mouse embryos. Nature 362:155-158.

Guenther J, Nick HP, Monard D (1985) A glia-derived neurite-promoting factor with protease inhibitory activity. EMBO J 4:19631966.

Gurwitz D, Cunningham DD (1988) Thrombin modulates and reverses neuroblastoma neurite outgrowth. Proc Natl Acad Sci USA 85:3440-3444.

Guttridge DC, Lau AL, Cunningham DD (1993) Protease nexin-1, a thrombin inhibitor, is regulated by interleukin- 1 and dexamethasone in normal human fibroblasts. J Biol Chem 268:18966-18974.

Heumann R, Lindholm D, Bandtlow C, Meyer M, Radeke MJ, Misko TP, Shooter E, Thoenen H (1987) Differential regulation of mRNA encoding nerve growth factor and its receptor in rat sciatic nerve during development, degeneration, and regeneration: role of macrophages. Proc Natl Acad Sci USA 84:8735-8739.

Hoffmann MC, Nitsch C, Scotti AL, Reinhard E, Monard D (1992) The prolonged presence of glia-derived nexin, an endogenous protease inhibitor, in the hippocampus after ischemia-induced delayed neuronal death. Neuroscience 49:397-408.

Iwasaki Y, Kinoshita M, Ikeda K, Shiojima T, Kurihara T, Appel SH (1991). Trophic effect of angiotensin II, vasopressin and other peptides on the cultured ventral sninal cord of rat embryo. I Neurol Sci 103:151-155

Kambayashi Y, Bardhan S, Takahashi K, Tsuzuki S, Inui H, Hamakubo $T$, Inagami $T$ (1993) Molecular cloning of a novel angiotensin II receptor isoform involved in phosphotyrosine phosphatase inhibition. J Biol Chem 268:24543-24546.

Kawasaki E (1990) Amplification of RNA. In: PCR protocols: a guide to methods and applications (Innis M, Gelfand D, Sninsky J, White T, eds), pp 21-27. San Diego: Academic.

Laufer R, Changeux J-P (1987) Calcitonin gene-related peptide elevates cyclic AMP levels in chick skeletal muscle: possible neurotrophic role for a coexisting neuronal messenger. EMBO J 6:901-906.

Lindholm D, Heumann R, Meyer M, Thoenen H (1987) Interleukin-1 regulates synthesis of nerve growth factor in non-neuronal cells of rat sciatic nerve. Nature 330:658-659.

Lund LR, Riccio A, Andreasen PA, Nielsen L, Kristensen P, Laiho M, Saksela O, Blasi F, Dano K (1987) Transforming growth factor- $\beta$ is a strong and fast acting positive regulator of the level of type-1 plasminogen activator inhibitor mRNA in WI-38 human lung fibroblasts. EMBO J 6:1281-1286.

Maniatis T, Fritsch EF, Sambrook J (1987) Molecular cloning: a laboratory manual. Cold Spring Harbor, NY: Cold Spring Harbor Laboratory.

Mansuy IM, van der Putten H, Schmid P, Meins M, Botteri FM, Monard D (1993) Variable and multiple expression of protease nexin-1 during mouse organogenesis and nervous system development. Development 119:1119-1134.

Matsuoka I, Meyer M, Thoenen H (1991) Cell type-specific regulation of nerve growth factor (NGF) synthesis in non-neuronal cells: comparison of Schwann cells with other cell types. J Neurosci 11:31653177.

McGrogan M, Kennedy J, Ping Li M, Hsu C, Scott RW, Simsonsen CC (1988) Molecular cloning and expression of two forms of human protease nexin-1. Biotechnology 6:172-177.

Meier R, Spreyer P, Ortmann R, Harel A, Monard D (1989) Induction of glia-derived nexin after lesion of a peripheral nerve. Nature 342 : 548-550.

Monard D (1988) Cell-derived proteases and protease inhibitors as regulators of neurite outgrowth. Trends Neurosci 11:541-544.

Monard D, Solomon F, Rentsch M, Gysin R (1973) Glia-induced morphological differentiation in neuroblastoma cells. Proc Natl Acad Sci USA 70:1894-1897.

Mukoyama M, Nakajima M, Horiuchi M, Sasamura H, Pratt RE, Dzau VJ (1993) Expression cloning of type 2 angiotensin receptor reveals a unique class of seven-transmembrane receptors. J Biol Chem 268: 24539-24542.

Murphy TJ, Wayne Alexander R, Griendling KK, Runge MS, Bernstein KE (1991) Isolation of a cDNA encoding the vascular type-1 angiotensin II receptor. Nature 351:233-236.

Nathan CF (1987) Secretory products of macrophages. J Clin Invest $79: 319-326$
Noguchi K, Senba E, Morita Y, Sato M, Tohyama M (1990) $\alpha$-CGRP and $\beta$-CGRP $m$ RNA are differentially regulated in the rat spinal cord and dorsal root ganglion. Mol Brain Res 7:299-304.

Nussberger J, Brunner DB, Waeber B, Brunner HR (1985) True versus immunoreactive angiotensin II in human plasma. Hypertension 7[Suppl I]:1-7.

Olson JA Jr, Shiverick KT, Ogilvie S, Buhi WC, Raizada MK (1991) Angiotensin II induces secretion of plasminogen activator inhibitor 1 and a tissue metalloprotease inhibitor-related protein from rat brain astrocytes. Proc Natl Acad Sci USA 88:1928-1932.

Otten U, Goedert M, Baumann JB, Girard G (1981) Stimulation of the pituitary-adrenocortical axis and induction of tyrosine hydroxylase by nerve growth factor are not dependent on mouse submaxillary gland isorenin. Brain Res 217:207-211.

Pellegrino RG, Politis MJ, Ritchie JM, Spencer PS (1986) Events in degenerating cat peripheral nerve: induction of Schwann cell S-phase and its relation to nerve fibre degeneration. J Neurocytol 15:17-28.

Pittman RN (1990) Developmental roles of proteases and inhibitors. Dev Biol 1:65-74

Raivich G, Dumoulin FL, Streit WJ, Kreutzberg GW (1992) Calcitonin gene-related peptide (CGRP) in the regenerating rat sciatic nerve. Restor Neurol Neurosci 4:107-115.

Reagan LP, Ye X, Maretzski CH, Fluharty SJ (1993) Down-regulation of angiotensin II receptor subtypes and desensitization of cyclic GMP production in neuroblastoma NIE-115 cells. J Neurochem 60:24-31.

Reinhard E, Meier R, Halfter W, Rovelli G, Monard D (1988) Detection of glia-derived nexin in the olfactory system of the rat. Neuron $1: 387-394$.

Reinhard E, Suidan H, Pavlik A, Monard D (1994) Glia-derived nexin/protease nexin-1 is expressed by a subset of neurons in the rat brain. J Neurosci Res 37:256-270.

Rogister B, Delree P, Leprice P, Martin D, Sadzot C, Malgrange B, Munaut C, Rigo JM, Lefebvre PP, Octave JN, Schoenen J, Moonen $G$ (1993) Transforming growth factor beta as a neuronoglial signal during peripheral nervous system response to injury. J Neurosci Res 34:32-43.

Sappino A-P, Madani RK, Huarte J, Belin D, Kiss JZ, Wohlwend A, Vassalli J-D (1993) Extracellular proteolysis in the adult murine brain. J Clin Invest 92:679-685.

Scotti AL, Monard D, Nitsch C (1994) Re-expression of glia-derived nexin/protease nexin-1 depends on lesion-induction or terminal degeneration: observations after excitotoxin or 6-hydroxydopamine lesions of rat substantia nigra. J Neurosci Res 37:155-168.

Shehab SA, Atkinson ME (1986) Vasoactive intestinal polypeptide (VIP) increases in the spinal cord after peripheral axotomy of the sciatic nerve originate from primary afferent neurons. Brain Res 376: 180-185.

Stone SR, Nick HP, Hofsteenge J, Monard D (1987) Glia-derived neurite-promoting factor is a slow-binding inhibitor of trypsin, thrombin and urokinase. Arch Biochem Biophys 252:237-244.

Suidan H, Stone S, Hemmings BA, Monard D (1992) Thrombin causes neurite retraction in neuronal cells through activation of cell surface receptors. Neuron 8:363-375.

Sumners C, Myers LM, Kalberg CJ, Raizada MK (1990) Physiological comparisons of angiotensin II receptors in neuronal and astrocyte glial cultures. Prog Neurobiol 34:355-385.

Tallant EA, Diz DI, Khosla MC, Ferrario CM (1991) Identification and regulation of angiotensin II receptors subtypes on NG108-15 cells. Hypertension 17:1135-1143.

Tsutsumi K, Saavedra JM (1991a) Characterization and development of angiotensin II receptor subtypes $\left(\mathrm{AT}_{1}\right.$ and $\left.\mathrm{AT}_{2}\right)$. Am J Physiol 261R:209-216.

Tsutsumi K, Saavedra JM (1991b) Heterogeneity of angiotensin II$\mathrm{AT}_{2}$ receptors in the rat brain. Mol Pharmacol 41:290-297.

Vaughan PJ, Cunningham DD (1993) Regulation of protease nexin-1 synthesis and secretion in cultured brain cells by injury-related factors. J Biol Chem 268:3720-3727.

Villar MJ, Cortes R, Theodorsson E, Wiesenfeld-Hallin Z, Schalling M, Fahrenkrug J, Hokfelt T (1989) Neuropeptide expression in rat dorsal root ganglion cells and spinal cord after peripheral nerve injury with special reference to galanin. Neuroscience 33:587-604.

Villcgas J, Evans PD, Reale V (1988) Electrophysiology of Schwann cell receptors. In: Glial cell receptors (Kimelberg HK, ed), pp 141157. New York: Raven. 
Whitebread S, Mele M, Kamber B, de Gasparo M (1989) Preliminary biochemical characterization of two angiotensin II receptor subtypes. Biochem Biophys Res Commun 163:284-291.

Whitebread S, Pfeilschifter J, Ramjoué H, de Gasparo M (1993) Angiotensin II binding sites on micro-organisms contaminating cell cultures. Regul Pept 44:233-238.

Wilkin GP, Cholewinski A (1988) Peptide receptors on astrocytes. In:
Glial cell receptors (Kimelberg HK, ed), pp 223-241. New York: Raven.

Zarahn ED, Ye X, Ades AM, Reagan L̄P, Fluharty S̄J (1992) Ángiotensin-induced c-GMP production is mediated by multiple receptor subtypes and nitric oxide in N1E-1 15 neuroblastoma cells. J Neurochem 58:1960-1963. 